\title{
On the first record of the exotic Moina macrocopa (Straus, 1820) in Minas Gerais State, Brazil
}

\author{
Rietzler, AC. *, Maia-Barbosa, PM., Ribeiro, MM. and Menendez, RM. \\ Laboratório de Limnologia, Ecotoxicologia e Ecologia Aquática, Departamento de Biologia Geral, \\ Instituto de Ciências Biológicas, Universidade Federal de Minas Gerais - UFMG, \\ Av.Antônio Carlos, 6627, CEP 31270-901, Belo Horizonte, MG, Brazil \\ *e-mail: rietzler@icb.ufmg.br
}

Received August 6, 2013 - Accepted August 13, 2013 - Distributed May 31, 2014

(With 8 figures)

Sampling at Pampulha Reservoir in Minas Gerais State in August of 2012 found Moina macrocopa, until now reported for South America only in a temporary pond in Rio de Janeiro State, Brazil (Elmoor-Loureiro et al., 2010) and similar environments in South America (Valdivia-Villar, 1988; Elias-Gutiérrez and Zamuriano-Claros, 1994; Paggi, 1997). The most recent inventory (checklist) of cladocerans for Minas Gerais State (Santos-Wisniewski et al., 2011) did not mention this species, indicating recent appearance.

Pampulha Reservoir is a eutrophic medium-sized reservoir with an area of $1.82 \mathrm{~km}^{2}$ and mean depth of $5.0 \mathrm{~m}$ (Bezerra-Neto and Pinto-Coelho, 2010), corresponding to the depth of the sampling site (Figure 1). Recent studies on this reservoir (Pinto-Coelho, 1998; Jaramillo and Pinto-Coelho, 2011) have reported Moina micrura among the Moinidae. In August of 2012, specimens of Moina macrocopa were also found in the central compartment of the reservoir, representing around $1 \%$ of the cladocerans. Samplings carried out in 2013, showed fluctuations in its numerical densities, with an increase in April (13\% of total cladocerans) and reduction in May and June $(0.03 \%$ in both months), suggesting an initial colonisation process for the species.

The morphological features of the specimens (Figures 2-8) are similar to the ones described by Goulden (1968) for Moina macrocopa of the Old World, differing only in the number of setae on the ventral rim, from 70 to 77, close to what was described by Paggi (1997) and Elmoor-Loureiro et al. (2010). The mean female and male lengths correspond to $1.14 \pm 0.06 \mathrm{~mm}(1.05-1.20 \mathrm{~mm} ; \mathrm{n}=10)$ and $0.92 \pm 0.05 \mathrm{~mm}(0.85-0.97 \mathrm{~mm} ; \mathrm{n}=4)$. Ephippia were not found in females from the reservoir nor in attempts to induce their production in the laboratory.

The studied environment corresponds with habitat descriptions of Moinidae, especially with regard to M. macrocopa, found mostly in temporary, shallow and/or eutrophic environments (Paggi, 1997; Thorp and Covich, 2001; Petrusek, 2002). Laboratory experiments conducted with field and culture water at $25^{\circ} \mathrm{C}$ have shown high reproduction and rapid turnover for this species (unpublished data). Mean fecundity of field and culture water treatments corresponded, respectively, to $37.0 \pm$
6.8 (26-44) and $120.6 \pm 48.3$ (55-203) neonates, and primiparous individuals were found within less than 3 days. This signifies very high reproductive ability, suggesting a high level of competitiveness if other pelagic cladocerans are kept in low densities.

Representatives of Moinidae are considered ruderal species (Romanovsky, 1985), showing high biotic potential but with a need for high food concentrations, being preferably found in productive or disturbed environments. Maia-Barbosa and Bozelli (2006), studying a lake impacted by bauxite (Lake Batata, Pará State, Brazil), found Moina minuta in abundance, especially in periods with higher amounts of organic detritus and algae attached to bauxite tailings.

On the other hand, Pampulha reservoir, besides being eutrophic, is highly contaminated by industrial effluents. Comparative sensitivity tests using $\mathrm{NaCl}$ conducted in the laboratory showed CE50 values of $1.0 \mathrm{mg} . \mathrm{L}^{-1}$ and $1.7 \mathrm{mg} . \mathrm{L}^{-1}$ for $M$. macrocopa and $D$. similis, respectively, indicating that $M$. macrocopa may be more sensitive than other cladocerans.

Other studies related to cladocerans introduced into lakes and reservoirs have discussed the factors involved in the establishment of daphnids. Daphnia lumholtzi, introduced into lakes of North America (Work and Gophen, 1999; Dzialowski et al., 2000), as well as into lakes and reservoirs of Brazil (Zanata et al., 2003; Simões et al., 2009), has been favoured in oligo-mesotrophic environments, with higher temperatures (subtropical environments) and low densities of potential competitors.

Biological invasions have been considered one of the main causes of biodiversity loss (Wittenberg and Cock, 2001; Simberloff, 2003). The presence of Moina macrocopa in the Pampulha Reservoir is of concern, not only because it is an opportunistic species but also with regard to environmental connectivity and dispersion possibilities (Rocha et al., 2005). A subject for future investigations should certainly be whether $M$. macrocopa establishes itself and succeeds in this and other reservoirs.

Acknowledgements - We wish to thank Dr. Lourdes Elmoor-Loureiro for confirming our identification of Moina macrocopa. 


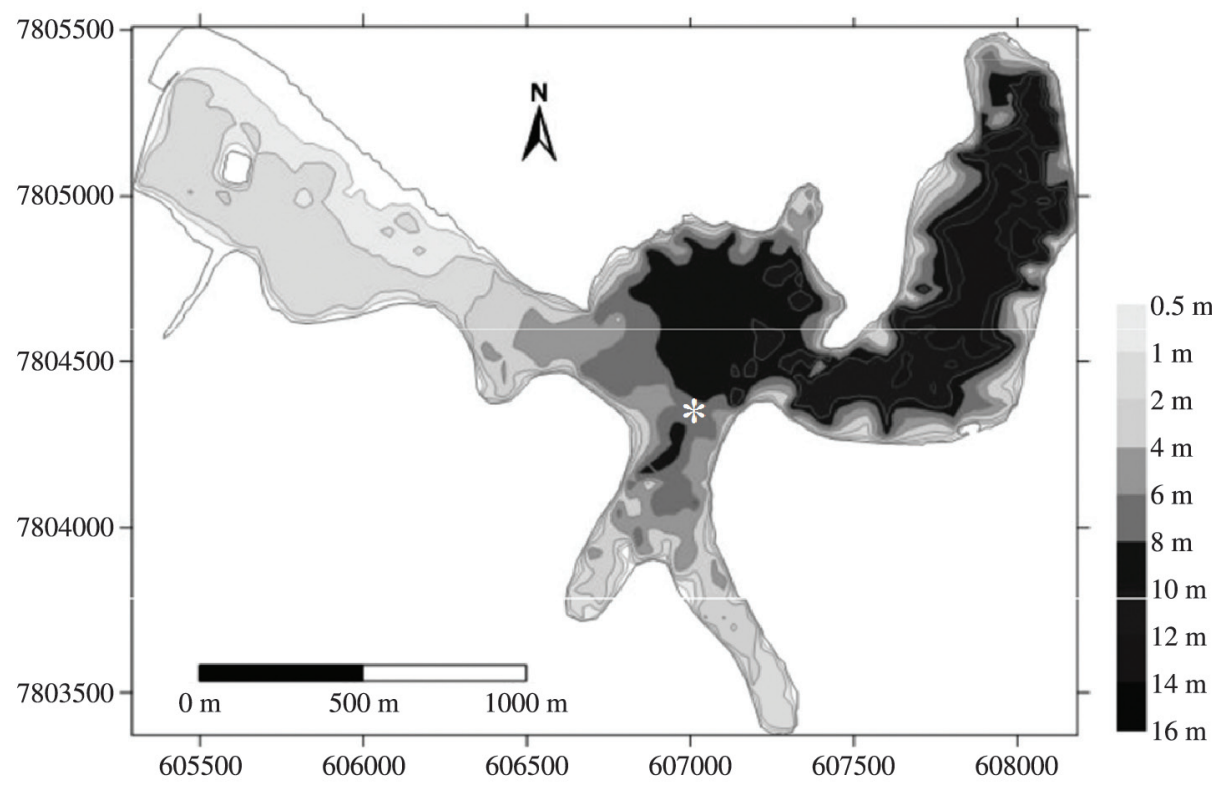

Figure 1. Bathymetry of Pampulha reservoir and sampling site of the present study $\left(_{*}\right)$ adapted from Bezerra-Neto and PintoCoelho (2010).
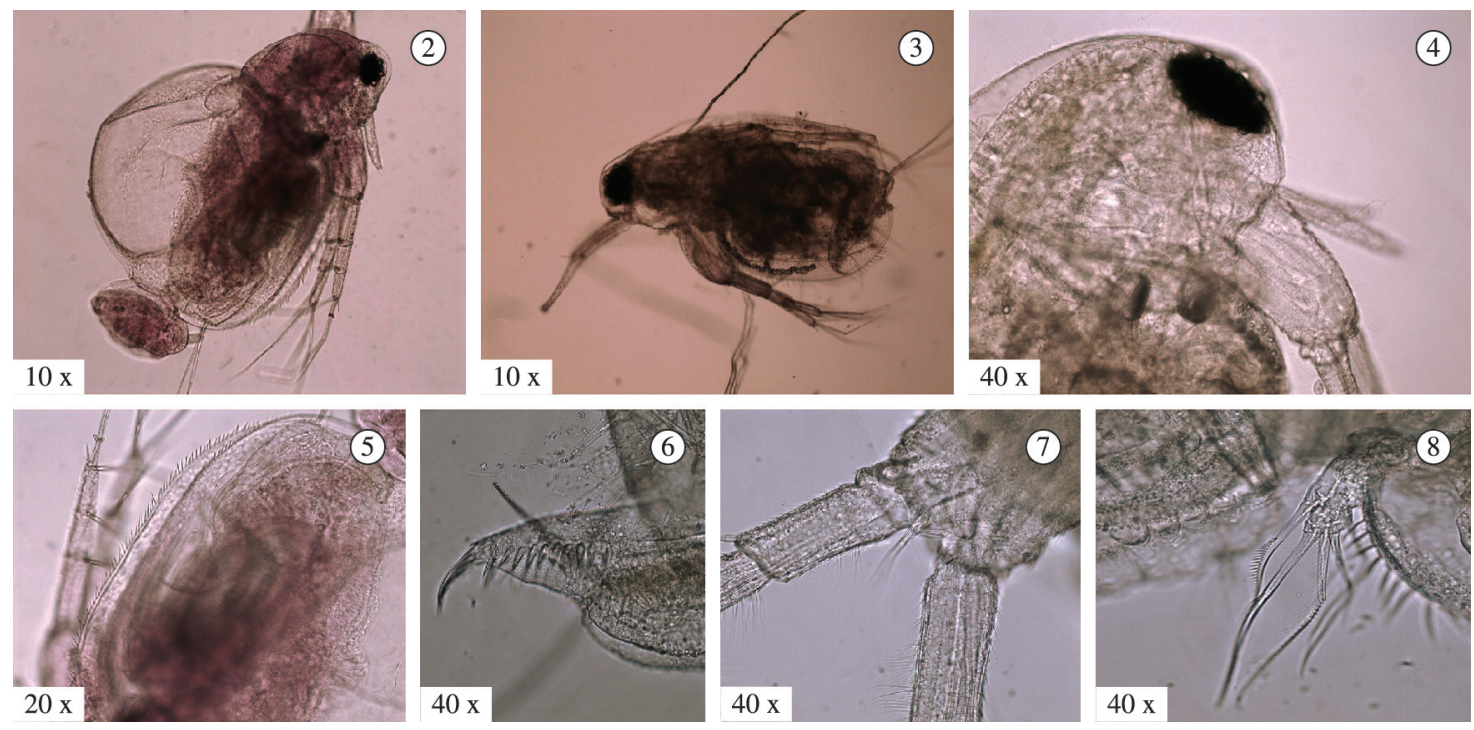

Figures 2-8. Moina macrocopa from Pampulha reservoir in Belo Horizonte, Minas Gerais state. 2) parthenogenetic female;

3) male; 4) detail of hairs on the head; 5) seta on the ventral margin; 6) postabdomen; 7) basal segment of antenna ramus; 8 ) first trunk limb, detailing the toothed setae of the penultimate segment and two terminal seta.

\section{References}

BEZERRA-NETO, JF. and PINTO-COELHO, RM., 2010. Nova batimetria do Reservatório da Pampulha com estimativa do volume de dragagem do compartimento $z<1,0 m$. Relatório Técnico- Científico. São Paulo: AMBITEC. 23 p.

DZIALOWSKI, AR., O’BRIEN, WJ. and SWAFFAR, SM., 2000. Range expansion and potential dispersal mechanisms of the exotic Cladoceran Daphnia lumholtzi. Journal of Plankton
Research, vol. 22, no. 12, p. 2205-2223. http://dx.doi.org/10.1093/ plankt/22.12.2205

ELIAS-GUTIÉRREZ, M. and ZAMURIANO-CLAROS, R., 1994. Primer registro de Moina macrocopa (Daphniiforme: Moinidae) em Bolivia. Revista de Biología, vol. 42, no. 1/2, p. 385.

ELMOOR-LOUREIRO, LMA., SANTANGELO, JM., LOPES, PM. and BOZELLI, RL., 2010. A new report of Moina macrocopa (Straus, 1820) (Cladocera, Anomopoda) in South America. 
Brazilian Journal of Biology, vol. 70, no. 1, p. 225-226. http:// dx.doi.org/10.1590/S1519-69842010000100031. PMid:20231982

GOULDEN, CE., 1968. The systematics and evolution of the Moinidae. Transactions of American Philosophical Society, vol. 58, no. 6, p. 1-101. http://dx.doi.org/10.2307/1006102

JARAMILLO, JC. and PINTO-COELHO, RM., 2011. Novo Atlas dos Organismos Zooplanctônicos do Reservatório da Pampulha, Belo Horizonte, MG. Available from: <http://ecologia.icb.ufmg. br/ rpcoelho/atlas/atlas.htm>. Access in: 20 May 2013.

MAIA-BARBOSA, PM. and BOZELLI, RL., 2006. Community structure and temporal dynamics of cladocerans in an Amazonian lake (Lake Batata, PA, Brazil) impacted by bauxite tailings. Acta Limnologica Brasiliensia, Botucatu, vol. 18, no. 1, p. 67-75.

PAGGI, JC., 1997. Moina macrocopa (Straus, 1920) (Branchiopoda, Anomopoda) in South America: another case of species introduction? Crustaceana, vol. 70, no. 8, p. 886-893. http:// dx.doi.org/10.1163/156854097X00500.

PETRUSEK, A., 2002. Moina (Crustacea: Anomopoda, Moinidae) in the Czech Republic: a review. Acta Societatis Zoologicae Bohemicae, vol. 66, p. 213-220.

PINTO-COELHO, RM., 1998. Effects of eutrophication on seasonal patterns of mesozooplankton in a tropical reservoir: a 4-year study in Pampulha Lake, Brazil. Freshwater Biology, vol. 40, no. 1, p. 159-173. http://dx.doi.org/10.1046/j.1365-2427.1998.00327.x.

ROCHA, O., ESPÍNDOLA, ELG., FENERICH-VERANI, N., VERANI, JR. and RIETZLER, AC.,2005. O problema das invasões biológicas em águas doces. In ROCHA, O. (Ed.). Espécies invasoras em águas doces - estudo de caso e propostas de manejo. São Carlos: EdUFSCar. p. 9-12.

ROMANOVSKY, YE., 1985. Food limitation and life-history strategies in cladoceran crustaceans. Archiv für Hydrobiologie Beiheft Ergebnisse der Limnologie, vol. 21, p. 363-372.
SANTOS-WISNIEWSKI, MJ., MATSUMURA-TUNDISI, T., NEGREIROS, NT., SILVA, LC., SANTOS, RM. and ROCHA, O., 2011. O estado atual do conhecimento da diversidade de Cladocera (Crustacea, Branchiopoda) nas águas doces do estado de Minas Gerais. Biota Neotropica, vol. 11, no. 3, p. 287-301. http://dx.doi.org/10.1590/S1676-06032011000300024.

SIMBERLOFF, D., 2003. Erradication-preventing invasions at the outset. Weed Science, vol. 51, no. 2, p. 247-253. http://dx.doi. org/10.1614/0043-1745(2003)051[0247:EPIATO]2.0.CO;2.

SIMÕES, NR., ROBERTSON, BA., LANSAC-TÔHA, FA., TAKAHASHI, EM., BONECKER, CC., VELHO, LFM. and JOKO, CY., 2009. Exotic species of zooplankton in the Upper Paraná River floodplain, Daphnia lumholtzi Sars, 1885 (Crustacea: Branchiopoda). Brazilian Journal of Biology, vol. 69, no. 2, sup. Suppl, p. 551-558. http://dx.doi.org/10.1590/S151969842009000300010. PMid:19738962

THORP, J. and COVICH, A., 2001. Ecology and Classification of North American Freshwater Invertebrates. London: Academic Press. 1028 p.

VALDIVIA-VILLAR, RS., 1988. Checklist of freshwater Cladocera from Perú. Amazoniana, vol. 10, p. 283-297.

WITTENBERG, R. and COCK, MJW., 2001. Invasive alien species. How to address one of the greatest threats to biodiversity: a toolkit of best prevention and management practices. Wallingford: CAB International. $228 \mathrm{p}$

WORK, KA. and GOPHEN, M., 1999. Factors which affect the abundance of an invasive cladoceran, Daphnia lumholtzi, in U.S. reservoirs. Freshwater Biology, vol. 42, no. 1, p. 1-10.

ZANATA, LH., ESPÍNDOLA, ELG., ROCHA, O. and PEREIRA, RHG., 2003. First record of Daphnia lumholtzi (SARS, 1885), exotic cladoceran, in São Paulo State (Brazil). Brazilian Journal of Biology, vol. 63, no. 4, p. 717-720. http://dx.doi.org/10.1590/ S1519-69842003000400019. PMid:15029383 